\title{
PERANCANGAN SIMA ASET TETAP KANTOR DESA DI WILAYAH KABUPATEN BANDUNG BARAT
}

\author{
Putri Dewi Purnama ${ }^{1}$, Husna Candranurani Oktavia ${ }^{1}$, Mariah Rabiatul Qibtiyah ${ }^{1}$, \\ Muhammad Raharso ${ }^{1}$, Gilang Ramadhan ${ }^{1}$ \\ ${ }^{1}$ Jurusan Administrasi Niaga, Politeknik Negeri Bandung \\ Email: mariah.rabiatul@polban.ac.id
}

\begin{abstract}
Abstrak
Teknologi informasi memudahkan dalam penanganan pekerjaan termasuk untuk mengelola aset. Sistem informasi manajemen aset (SIMA) terus berkembang seiring dengan pertumbuhan aplikasi dari teknologi informasi terkini. Berbagai perangkat lunak dan perangkat keras sangat berperan dalam pengelolaan data dan informasi aset diberbagai organisasi, baik pemerintahan maupun swasta. Namun, untuk tingkat organisasi publik yang lebih rendah, dalam hal ini adalah pemerintahan desa belum menerapkan sistem manajemen aset terkini untuk mencatat, mendata, dan melaporkan hasil inventarisasi aset. Permasalahan yang ada di Kantor Desa di wilayah Kabupaten Bandung Barat adalah belum adanya sistem informasi manajemen aset untuk mendukung proses inventarisasi aset tetap dikantor tersebut sehingga menyebabkan sulitnya mengidentifikasi aset (lokasi, jumlah, kualitas, pengguna, dll). Dengan adanya sistem ini, diharapkan proses pencatatan aset yang dimiliki oleh kantor desa jauh lebih mudah untuk dicatat, direncanakan kebutuhannya dan sekaligus dapat dilaporkan jumlah, kualitas dan kinerja aset yang dimiliki. Kegiatan Pengabdian Kepada Masyarakat (PKM) melalui Program Kemitraan Masyarakat antara pihak kampus Politeknik Negeri Bandung dengan Kantor Desa di Kabupaten Bandung Barat adalah merancang sebuah aplikasi SIMA Aset Tetap Kantor Desa untuk memudahkan perangkat-perangkat desa dalam melakukan pengelolaan aset berupa identifikasi, pencatatan, dan pelaporan aset. Sistem ini lebih fokus pada kegiatan inventarisasi aset yaitu untuk pendataan, pencatatan, dan pelaporan aset. Selain itu, Tim PKM juga melakukan sosialisasi penggunaan aplikasi tersebut kepada perangkat desa. Tahap selanjutnya adalah melakukan follow up ke kantor desa sebagai salah satu upaya monitoring dan evaluasi penggunaan aplikasi tersebut. Hasil dari kegiatan PKM ini yaitu berupa database/SIMA aset tetap kantor desa, video tutorial, dan modul pelatihan penggunaan aplikasi SIMA.
\end{abstract}

Kata kunci: Sistem informasi manajemen aset, inventarisasi aset, Kabupaten Bandung Barat 
DIFUSI

Volume 3, No.2 Juli 2020

\section{PENDAHULUAN}

Teknologi merupakan sarana yang digunakan untuk kelangsungan, kenyamanan dan kemudahan hidup manusia. Saat ini, teknologi diperlukan dalam hal pengelolaan aset yang ada di dalam organisasi atau yang biasa disebut dengan Sistem Informasi Manajemen Aset (SIMA) untuk memudahkan identifikasi dan penatausahaan aset. Kegiatan identifikasi dan penatausahaan bertujuan untuk memperoleh informasi yang akurat, lengkap dan mutakhir mengenai kekayaan daerah yang dimiliki atau dikuasai oleh pemerintah daerah [1]. SIMA adalah kumpulan elemen-elemen yang terintegrasi untuk mengolah data menjadi informasi mengenai aset. Tujuan dari SIMA yaitu untuk pengamanan aset, tertib administrasi dan pengendalian atau pengawasan aset. Pengelolaan aset juga mendukung kegiatan operasional suatu instansi setiap harinya, tidak adanya informasi yang tepat untuk mengelola aset dapat menghambat kegiatan operasional.

Menurut Hartono dalam [2] tertib dokumen aset berkaitan dengan upaya penyediaan dan pendataan dokumen yang menyertai keberadaan aset, sedangkan tertib administrasi lebih dimaksudkan pada upaya membangun prosedur pengelolaan aset mulai saat pengadaan, perubahan data, hingga penghapusan aset. Penatausahaan adalah sebuah konsep dalam membuat prosedur kegiatan pengelolaan aset atau Barang Milik Daerah (BMD) yang terdiri dari pembukuan, inventarisasi dan pelaporan asset/ BMD [3]. Kegiatan penatausahaan disusun pada buku inventaris yang menunjukkan semua kekayaan daerah yang bersifat kebendaan bergerak maupun yang tidak bergerak. Buku inventaris juga memuat data berupa nomor, spesifikasi barang, bahan, asal/cara perolehan barang, ukuran barang/konstruksi, satuan, keadaan barang, jumlah barang dan harga, serta keterangan [4].

Penatausahaan BMD dimulai dari unit terkecil dalam pemerintahan daerah yaitu pada kantor desa. Kantor desa memerlukan sistem inventarisasi aset tetap untuk memudahkan dalam pendataan, pencatatan, pelaporan, pengawasan dan pertanggungjawaban pengguna aset. Salah satu permasalahan yang ada di kantor desa yaitu belum memiliki sistem informasi manajemen aset untuk mendukung kegiatan inventarisasi aset tetap. Kegiatan inventarisasi aset dilakukan secara manual dengan menggunakan buku besar dan aplikasi Microsoft Word sederhana dan tidak rutin dilakukan. Hal tersebut dinilai tidak efisien karena jumlah aset yang dimiliki kantor desa tidak sedikit sehingga menghabiskan waktu yang banyak dalam melakukan pencatatan aset. Selain itu, sulitnya melaporkan jumlah dan kualitas aset yang dimiliki secara pasti karena tidak tertib nya administrasi pencatatan aset. Berdasarkan permasalahan tersebut maka perlu dilakukan perancangan Sistem Informasi Manajemen Aset (SIMA) mengenai inventarisasi aset tetap pada kantor desa di Wilayah Kabupaten Bandung Barat.

\section{METODE}

Metode pelaksanaan program pengabdian kepada masyarakat dimulai dengan melakukan observasi awal ke kantorkantor desa wilayah Kabupaten Bandung 
DIFUSI

Volume 3, No.2 Juli 2020

Barat untuk mengetahui sistem pencatatan aset tetap yang dilakukan oleh perangkat kantor desa. Hasil observasi awal ditemukan beberapa permasalahan yang selanjutnya dianalisis lebih mendalam dengan melakukan wawancara kepada perangkat desa terkait dengan kegiatan penatausahaan aset tetap kantor desa. Dari hasil observasi didapatkan informasi bahwa penatausahaan aset masih dilakukan secara manual, sehingga perlu dibuat rancangan aplikasi sistem informasi manajemen aset tetap untuk memudahkan proses penatausahaan aset tetap di kantor desa. Tahapan-tahapan pelaksanaan program pengabdian kepada masyarakat adalah sebagai berikut:

\section{Focus Group Discussion}

Diskusi awal terkait dengan penentuan konsep dan konten mengenai aplikasi sistem informasi manajemen aset tetap yang akan dibuat untuk memudahkan kegiatan penatausahaan/inventarisasi aset oleh perangkat desa.

\section{Perancangan SIMA}

Perancangan aplikasi sistem informasi manajemen aset tetap dengan menggunakan software Microsoft Office Access. Konsep dari aplikasi berfokus pada cara pencatatan aset dengan menggunakan format-format yang telah disesuaikan dengan Peraturan Pemerintah [5] tentang pedoman teknis pengelolaan Barang Milik Negara/Daerah. Format yang dirancang di dalam aplikasi SIMA berupa Kartu Inventaris Barang (KIB) sebagai menu utama yang digunakan untuk mencatat aset-aset tetap yang terbagi menjadi 7 golongan.

\section{Pilot Test}

Dilakukan uji coba penggunaan aplikasi SIMA yang telah selesai terlebih dahulu untuk mengetahui ada atau tidaknya kegagalan sistem ataupun kesalahan-kesalahan yang muncul dari segi teknis dan konten.

\section{Revisi Aplikasi SIMA}

Revisi dilakukan setelah diketahui adanya kesalahan baik secara teknis maupun secara konten dengan cara melakukan penambahan kolom-kolom tugas di masing-masing menu sesuai dengan standar dari peraturan pemerintah. Selain itu juga dilakukan perbaikan terkait dengan tombol aksi untuk penginputan dan penyimpanan data.

\section{Sosialisasi Aplikasi}

Aplikasi yang sudah dilakukan perbaikan secara teknis dan isi konten, selanjutnya dilakukan sosialisasi penggunaan kepada 10 kantor desa di wilayah Kabupaten Bandung Barat dan pemberian aplikasi kepada perangkat desa. Pada tahap ini tim PKM memberikan sosialisasi mengenai cara penggunaan aplikasi SIMA dengan memandu langsung perangkat desa saat melakukan praktek penggunaan aplikasi dengan menggunakan komputer. Materi mengenai inventarisasi aset dan sistem informasi manajemen aset disampaikan sebagai bentuk dari tambahan informasi untuk perangkat desa mengenai penerapan kegiatan inventarisasi aset di kantor desa. 
DIFUSI

Volume 3, No.2 Juli 2020

\section{Pemantauan}

Dilakukan pemantauan langsung ke kantor desa setelah sosialisasi penggunaan aplikasi dengan jarak waktu 2 (dua) minggu. Tujuan dari pemantauan adalah untuk mengetahui apakah terdapat kendala atau kesulitan yang dialami perangkat desa dalam menggunakan/ mengoperasikan aplikasi yang telah diberikan.

\section{HASIL DAN PEMBAHASAN}

Langkah awal dalam perancangan aplikasi adalah focus group discussion terkait konsep dan konten yang dimasukan ke dalam aplikasi SIMA aset tetap dalam bentuk Microsoft Access. Focus Group Discussion juga dilakukan untuk menentukan format Kartu Inventaris Barang (KIB) yang sesuai dengan peraturan pemerintah yaitu Permendagri No. 17 Tahun 2007 tentang pedoman teknis pengelolaan barang milik daerah, dimana Kartu Inventaris Barang berfungsi dalam proses pencatatan aset tetap.

Aplikasi SIMA yang dirancang memiliki beberapa action (tindakan) seperti pendaftaran username, login, input data, simpan rekaman data, ubah rekaman data, cetak laporan, eksport data ke Microsoft Excel dan kembali ke halaman utama. Aplikasi SIMA dirancang dengan menyesuaikan kebutuhan perangkat desa dalam melakukan kegiatan inventarisasi aset KIB yang akan menjadi menu utama dari aplikasi SIMA terbagi menjadi beberapa klasifikasi sebagai berikut:

a. KIB Tanah

b. KIB Mesin dan Peralatan c. KIB Gedung dan Bangunan

d. KIB Jalan, Irigasi dan Jaringan

e. KIB Aset Tetap lainnya

f. KIB Konstruksi dalam pengerjaan

g. Kartu Invetaris Ruangan, dan

h. Buku Inventarisasi

Tampilan aplikasi yang dibuat dapat dilihat pada Gambar 1.

Aplikasi SIMA yang dirancang memiliki beberapa action (tindakan) seperti pendaftaran username, login, input data, simpan rekaman data, ubah rekaman data, cetak laporan, eksport data ke Microsoft Excel dan kembali ke halaman utama. Aplikasi SIMA dirancang dengan menyesuaikan kebutuhan perangkat desa (dalam hal ini disebut sebagai pengguna) dengan tampilan interface aplikasi yang bersifat user friendly agar mudah digunakan. Ketika pengguna sudah masuk kedalam sistem (login) maka pengguna dapat memilih menu KIB yang dibutuhkan untuk melakukan input data, edit, hapus, ataupun cetak data.

Pembuatan aplikasi menghabiskan waktu selama 1 (satu) bulan dengan dua luaran yang didapatkan yaitu berupa aplikasi SIMA dan video tutorial. Sebelum dilakukan sosialisasi dilakukan pilot test oleh tim PKM untuk melihat apakah terdapat cacat pada sistem maupun teknis pada aplikasi. Setelah kesalahan dan kekurangan ditemukan maka dilakukan perbaikan untuk menyempurnakan aplikasi sebelum disosialisasikan kepada perangkat desa. Tahap selanjutnya adalah kegiatan sosialisasi berupa penyampaian materi terkait inventarisasi aset dan sistem informasi manajemen aset serta praktek penggunaan aplikasi SIMA dengan bimbingan langsung dari tim PKM. Sosialisasi dilakukan pada hari Kamis 
DIFUSI

Volume 3, No.2 Juli 2020

tanggal 10 Oktober 2019 berlokasi di Gedung P2T Ruang Laboratorium Komputer 8, Lt. 3 Politeknik Negeri Bandung. Kegiatan sosialisasi berlangsung dari pukul 08.00 hingga pukul 11.30 WIB.

Kegiatan sosialisasi dihadiri oleh 16 perwakilan perangkat desa dari kantor desa di wilayah Kabupaten Bandung Barat. Peserta pelatihan mendapatkan seminar kit yang terdiri dari materi sosialisasi, notebook, pulpen, map plastik, paper bag, DVD yang berisi aplikasi SIMA dan video tutorial penggunaan aplikasi SIMA. C dapat dilihat pada Gambar 2.

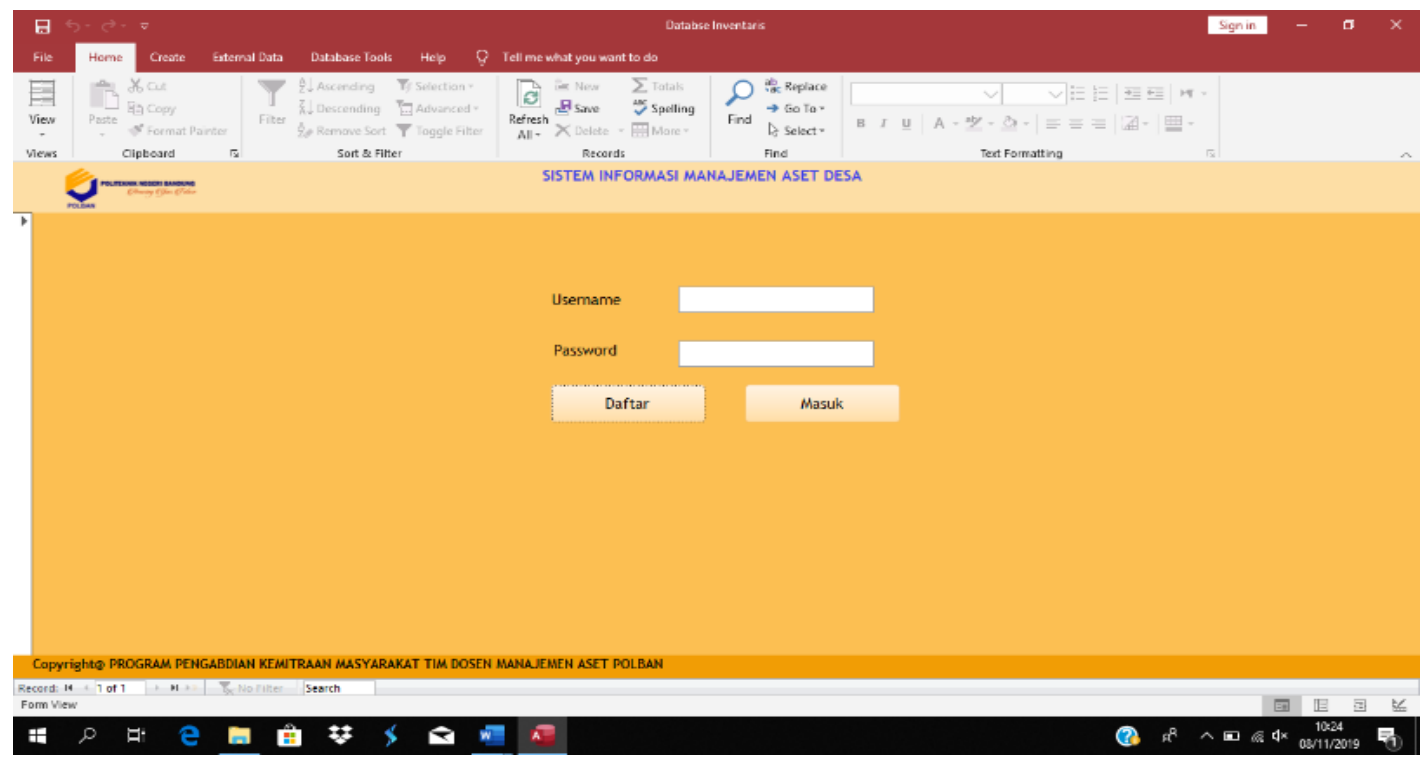

Gambar 1. Tampilan Aplikasi yang Dibuat

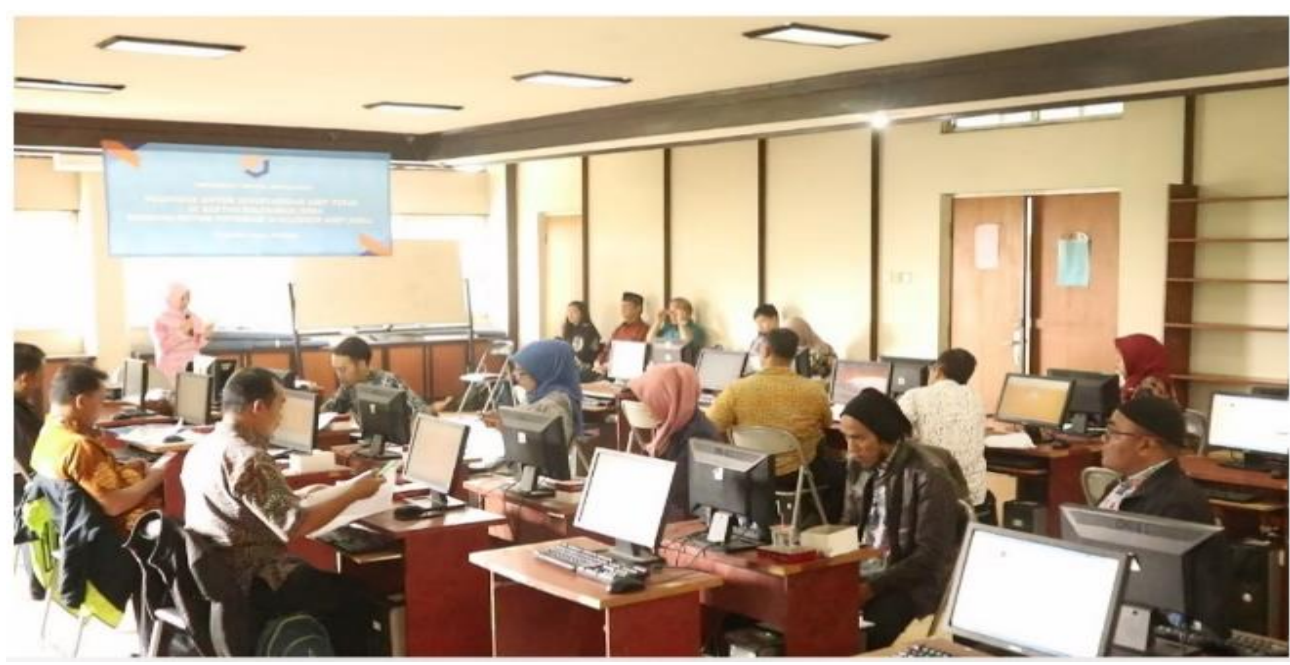

Gambar 2. Dokumentasi Kegiatan Sosialisasi yang Dilakukan 
DIFUSI

Volume 3, No.2 Juli 2020

Tahap akhir dari kegiatan yang dilakukan tim PKM adalah melakukan kegiatan pemantauan penggunaan aplikasi dengan cara melakukan kunjungan ke kantor-kantor desa secara random. Dalam kunjungan tersebut, tim pelaksana berdiskusi dengan perangkat desa mengenai hambatan yang ditemui terkait dengan penggunaan aplikasi SIMA. Dari hasil diskusi didapatkan informasi bahwa aplikasi sangat berguna karena bersifat user friendly dan sangat sederhana sehingga mudah untuk dioperasikan. Pada kesempatan tersebut tim pelaksana juga memberikan modul fisik untuk perangkat desa sebagai pedoman dalam menggunakan aplikasi serta memberikan informasi pemahaman mengenai sistem informasi manajemen aset dan inventarisasi aset tetap.. Dokumentasi kegiatan pemantauan yang dilaksanakan dua minggu setelah kegiatan sosialisasi dapat dilihat pada Gambar 3.

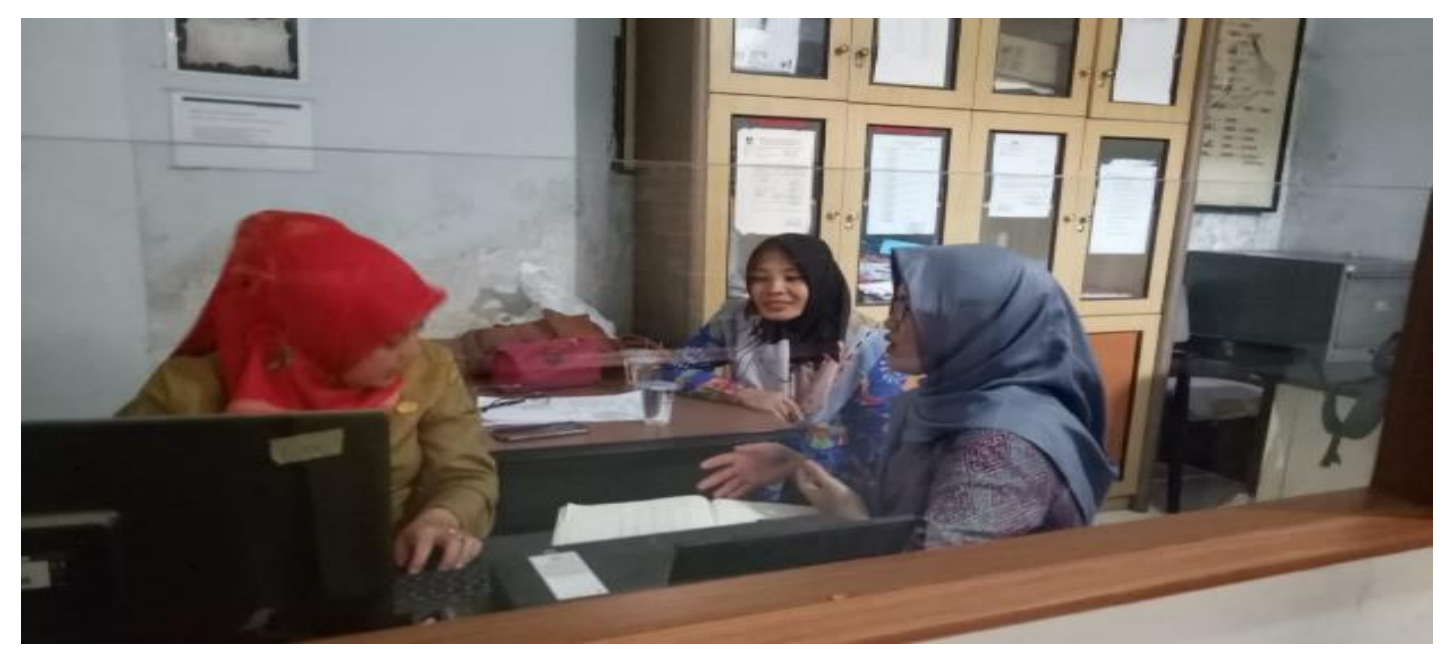

Gambar 3. Dokumentasi kegiatan pemantauan

Tahap finalisasi lainnya adalah pembuatan laporan akhir kegiatan pengabdian masyarakat yang ditujukan kepada Unit Penelitian dan Pengabdian Masyarakat (UPPM) Polban. Penyusunan laporan akhir disertai dengan dokumen administratif dan output berupa aplikasi SIMA inventarisasi aset yang mendukung terlaksananya program ini dengan baik.

\section{KESIMPULAN}

Berdasarkan kegiatan yang telah dilakukan dapat disimpulkan bahwa penatausahaan aset tetap pada kantor desa di wilayah Kabupaten Bandung Barat masih sangat minim dan dilakukan secara manual. Hal ini menyebabkan sulitnya mengidentifikasi aset tetap yang dimiliki kantor desa dan tidak diketahui secara pasti kualitas aset karena tidak terlaksananya tertib administrasi. Berdasarkan hal tersebut, kegiatan PKM yang telah dilakukan menghasilkan beberapa luaran, yakni:

a. Aplikasi SIMA Inventarisasi aset dalam bentuk Microsoft Access yang telah dirancang dan dikonsep sesuai dengan kebutuhan perangkat 
desa untuk melakukan kegiatan pencatatan aset di setiap kantor-kantor desa.

b. Telah dilakukan sosialisasi penggunaan aplikasi SIMA Inventarisasi Aset dalam rangka peningkatan pemahaman kegiatan inventarisasi aset melalui Sistem Informasi Manajemen Aset.

c. Melalui aplikasi SIMA inventtarisasi aset, perangkat desa sudah mampu memanfaatkan aplikasi yang telah diberikan untuk melaksanakan kegiatan pencatatan aset karena aplikasi dinilai sederhana dan bersifat user friendly saat dioperasikan.

\section{UCAPAN TERIMAKASIH}

Artikel ini tidak lepas dari kontribusi banyak pihak yang telah membantu terutama kepada pihak UPPM Polban yang telah mendanai dan mendukung kegiatan program pengabdian masyarakat ini. Selain itu kami juga mengucapkan terimakasih kepada para perangkat desa yang menjadi mitra dalam program PKM ini yang telah bersedia mengikuti sosialisasi dan berkenan menggunakan aplikasi kami sebagai bagian dari operasional dalam kegiatan dikantor desa. Tidak lupa juga kami ucapkan terima kasih kepada tim jurnal DIFUSI dan para reviewer yang telah banyak memberikan kritik dan saran sehingga artikel ini dapat dipublikasikan. Besar harapan kami artikel ini dapat bermanfaat dan dapat menjadi salah satu rujukan dalam melakukan penatausahaan aset agar lebih baik lain.

\section{REFERENSI}

[1] E. Widayanti, "Pengaruh Manajemen Aset Terhadap Optimalisasi Pemanfaatan Aset Tetap Pemerintah Daerah (Studi Kasus di Kabupaten Sragen)," Master, Universitas Sebelas Maret, Surakarta, 2010.

[2] D. S. Sriyanto, "Rancang Bangun Sistem Informasi Manajemen Aset Berbasis Web untuk Optimalisasi Penelusuran Aset di Teknik Industri UNDIP," Jurnal Teknik Industri, 11(3), pp. 187-196, 2016.

[3] A. Rachmawati, Herawati, dan Arnan, "Optimalisasi Penggunaan Teknologi Informasi dalam Penatausahaan Asset/ Barang Milik Daerah," Jurnal Aset (Akuntansi Riset), 10(2), pp. 189-197, 2018.

[4] Jamaludin, "Pengaruh Inventarisasi Aset, Legal Audit Aset, dan Penilaian Aset terhadap Optimalisasi Aset tetap (Tanah dan Bangunan) Milik Pemerintah Provinsi NTB," Jurnal Sekuritas, 1(1), pp. 2581-2696, 2017.

[5] Peraturan Menteri Dalam Negeri, "Pedoman Teknis Pengelolaan Barang Milik Daerah," Jakarta, 2017. 